\title{
Effects of mixed culture of Bacillus subtilis and Lactobacillus acidophilus on Cheonggukjang quality
}

\author{
Eun Ho Jang, Donghun Nam, Ha Gyoon Na, Ki-Hyo Jang* \\ Department of Food and Nutrition, Kangwon National University, Samcheok 25949, Korea
}

\section{Bacillus subtilis와 Lactobacillus acidophilus 복합사용이 청국장 품질특성에 미치는 영향 연구}

\author{
장은호·남동훈 - 나하균 - 장기효* \\ 강원대학교 식품영양학과
}

\begin{abstract}
In this study, the quality characteristics of Cheonggukjang prepared with the mixed culture of Bacillus subtilis and Lactobacillus acidophilus were investigated. One of the most common characteristics of Cheonggukjang is the formation of viscous substance, which is the mixture of a fructose polymer and poly-gamma-glutamic acid. After the first Cheonggukjang fermentation, sucrose (0, 2.5, and $7.5 \%)$ and a Lactobacillus acidophilus strain, containing the enzyme responsible for the production of exopolysaccharide, were supplemented, and then the second fermentation was carried out at $40^{\circ} \mathrm{C}$ for $48 \mathrm{~h}$. Changes in soluble solid contents, extension of viscous substance, pH, reducing sugar, amino-type and ammonia-type nitrogen content, enzyme activities, including a-amylase and protease, and isoflavone content were evaluated. The presence of sucrose in the starting fermentation materials decreased $\mathrm{pH}$, aglycone-formed isoflavone, amino-type nitrogen, and protease activity, however, increased extension of viscous substance. Growth of acid-producing microbes, including L. acidophilus KCTC 3925, was stimulated by sucrose. In conclusion, the present study indicated that the mixed culture of $B$. subtilis and $L$. acidophilus changes the quality characteristics of Cheonggukjang, increasing formation of viscous substance.
\end{abstract}

Key words : Cheonggukjang, mixed culture, mucoid substances, sucrose

\section{서 론}

청국장(Cheonggukjang)은 대두를 단시간 발효시켜 만드 는 발효식품으로 탄수화물이 주식인 우리나라의 식단에서 부족한 단백질과 지방을 공급해주는 주요한 에너지공급원 이며 저염식품이다. 청국장의 꾸준한 섭취는 만성퇴행성질 환 예방, 발암물질 억제, 간기능 개선, 혈전용해능 향상 및 당뇨병 예방 등에 도움이 된다(1-6). 청국장의 원료가 되는 대두에는 phytochemical의 일종인 이소플라본이 대부분 배

*Corresponding author. E-mail : kihyojang@kangwon.ac.kr Phone : 82-33-540-3312, Fax : 82-33-540-3319

Received 16 July 2018; Revised 18 August 2018; Accepted 20 August 2018.

Copyright (c) The Korean Society of Food Preservation. All rights reserved.
당체 형태로 존재하며 비배당체 형태인 다이드제인(daidzein), 제니스테인(genistein), 글리시테인(glycitein)은 배당체 이 소플라본의 약 $3 \%$ 이하로 존재한다(7). 대두 발효식품에서 는 발효미생물 유래의 $\beta$-glucosidase의 작용에 의하여 전체 이소플라본 함량 대비 비배당체 이소플라본 함량이 높게 나타난다. $\mathrm{Kim}$ 등(7)이 보고한 된장 14 종과 청국장 5종의 이소플라본 함량 분석 연구에서는 된장의 다이드제인과 제니스테인 함량은 각각 37-783과 23-714 $\mathrm{\mu g} / \mathrm{g}$, 청국장의 다이드제인과 제니스테인 함량은 각각 53-210과 7-169 $\mu \mathrm{g} / \mathrm{g}$ 로 나타나서 전체 이소플라본 함량 대비 비배당체 이소플라 본 함량 비율은 청국장이 된장보다 낮았다. 이러한 두 가지 장류에서의 비배당체 이소플라본 함량차이는 발효 및 숙성 기간의 차이에서 기인한다. 일반적으로 청국장 발효와 숙 성에 2-3일 소요되는 데 반하여 된장은 수개월에서 수년의 시간이 필요하다. 청국장의 낮은 비배당체 이소플라본 함 
량을 증가시키는 것은 청국장의 기능성을 개선하는 측면에 서 매우 중요하다.

청국장이 다른 대두 발효식품들과의 뚜렷한 차이점은 청국장 표면에 levan과 poly- - -glutamic acid(PGA)로 이루어 져 있는 점질물(mucoid)의 생성에 있다. 청국장의 levan은 과당이 $\beta-2,6$ 결합으로 이루어진 단순 다당류(homo polymer)인 반면, PGA는 글루탐산 중합체로 카르복실기와 아미노기가 아마이드 결합된 형태로 이루어져 있다 $(8,9)$.

일반적으로 청국장 제조 시 Bacillus 균을 단일 종균 (starter)으로 사용하지만, 추가적인 유산균의 사용 시 청국 장에서 y-amino-n-butyric acid(GABA) 함량 증가, 청국장의 이취감소 등의 효과가 있다 $(10,11)$. 선행연구에서는 Lactobacillus acidophilus KCTC 3925가 $\beta$-glucosidase 활 성이 우수하고, 설탕 첨가 배지에서 glucan 형태의 exopolysaccharide(EPS) 생성능이 있으며, $6.6 \%$ 이하의 소 금 농도에서 생육이 촉진됨을 확인하였다(12). 본 연구에서 는 청국장 제조 시 상업용 청국장 종균(Bacillus subtilis)과 Lacidophilus KCTC 3925를 동시에 사용하여 청국장 제조 시 청국장의 품질과 점질물 생성에 변화가 있을 것이라는 가설을 설정하고 연구를 진행하였다.

\section{재료 및 방법}

\section{실험재료 및 종균배양}

실험에 사용된 대두는 2016년산 콩(백태, 강원도 삼척, 국산)을 구입하여 $4^{\circ} \mathrm{C}$ 에서 냉장보관하면서 실험에 사용하 였다. 청국장 제조용 종균으로 사용된 Bacillus subtilis BN-NUC1(NUC Co., Deagu, Korea) 배양을 위하여 Soybean broth(DIFCO, St. Luois, MO, USA) $100 \mathrm{~mL}$ 에 동결 건조된 균 $0.2 \mathrm{~g}$ 을 첨가하고 $37^{\circ} \mathrm{C}$ 에서 24 시간 배양하였다. $L$. acidophilus KCTC 3925(Cellbiotech Co., Gimpo, Korea) 배 양을 위하여 $\mathrm{MRS}$ broth $100 \mathrm{~mL}$ 에 동결 건조된 균 $0.1 \mathrm{~g}$ 을 넣어 $37^{\circ} \mathrm{C}$ 에서 24 시간 배양한 후 사용하였다.

\section{청국장발효}

세척하여 불린 대두를 1 시간 동안 상온에서 건조시킨 후 $121^{\circ} \mathrm{C}$ 에서 40 분 동안 증자하였다. 상온으로 식혀서 증자 한 대두에 B. subtilis $\mathrm{BN}-\mathrm{NUC1}$ 을 접종하고 $40^{\circ} \mathrm{C}$ 에서 48 시 간 발효하여 1 차 발효된 청국장을 제조하였다. 2 차 발효는 1 차 발효된 청국장에 Table 1과 같은 조성으로 유산(lactic acid), 설탕과 $L$ acidophilus KCTC 3925 를 첨가하고 $40^{\circ} \mathrm{C}$ 에 서 추가적으로 48 시간 동안 2 차 발효하였다. 대조군인 Con 의 경우, 1 차 발효된 청국장에 설탕농도가 각각 $0,2.5,7.5 \%$ 가 되도록 조정한 후, $40^{\circ} \mathrm{C}$ 에서 48 시간 동안 2 차 발효하였 다. 비교군인 with a starter supplementation(WS)의 경우, 1 차 발효된 $40 \mathrm{~g}$ 의 청국장에 $2 \%$ 가 되게끔 유산을 첨가한
후, 여기에 설탕농도가 각각 $0,2.5,7.5 \%$ 가 되도록 조정한 후 L acidophilus KCTC 3925를 접종하여 2차 발효하였다. 또 다른 비교군인 with sterilization process and a starter supplementation(WSS)의 경우, 1 차 발효된 $40 \mathrm{~g}$ 의 청국장에 $2 \%$ 가 되게끔 유산을 첨가하고, 여기에 설탕농도가 각각 $0,2.5,7.5 \%$ 가 되도록 조정한 후 $100^{\circ} \mathrm{C}$ 에서 15 분 동안 열처 리하고 L. acidophilus KCTC 3925 를 접종하여 $40^{\circ} \mathrm{C}$ 에서 48시간 2차 발효하였다. 1차 발효에 사용된 B. subtilis BN-NUC1과 2차 발효에 사용된 L acidophilus KCTC 3925 는 각각 증자된 대두 무게의 $0.5 \%$ 수준으로 사용하였다.

Table 1. Proportion of fermented Cheonggukjang with different sugar contents

\begin{tabular}{cccc}
\hline Groups $^{1)}$ & Sterilization $^{2)}$ & Sucrose $(\%)$ & Starter $^{3)}(\mathrm{mL})$ \\
\hline Con & No & - & - \\
WS & No & - & 0.5 \\
WSS & Yes & - & 0.5 \\
\hline Con (2.5S) & No & 2.5 & - \\
WS (2.5S) & No & 2.5 & 0.5 \\
WSS (2.5S) & Yes & 2.5 & 0.5 \\
\hline Con (7.5S) & No & 7.5 & - \\
WS (7.5S) & No & 7.5 & 0.5 \\
WSS (7.5S) & Yes & 7.5 & 0.5 \\
\hline
\end{tabular}

${ }^{1)}$ Con, prior to $2^{\text {nd }}$ fermentation, either $0,2.5,7.5 \%$ of sucrose was supplemented to fermentation broth then $2^{\text {nd }}$ fermentation was carried out at $40^{\circ} \mathrm{C}$ for $48 \mathrm{~h}$; WS, to fermentation broth containing $40 \mathrm{~g}$ of Cheonggukjang and 2\% lactic acid, sucrose solution was supplemented as indicated in Table 1 and $2^{\text {nd }}$ fermentation was carried out at $40^{\circ} \mathrm{C}$ for $48 \mathrm{~h}$ using L a acidophilus KCTC 3925 ; WSS, to fermentation broth, sucrose solution was supplemented and then heat-sterilized at $100^{\circ} \mathrm{C}, 15 \mathrm{~min}$. $2^{\text {nd }}$ fermentation was carried out at $40^{\circ} \mathrm{C}$ for $48 \mathrm{~h}$ using $L$. acidophilus KCTC 3925.

${ }^{2)}$ Sterilization at $100^{\circ} \mathrm{C}$ for $15 \mathrm{~min}$.

${ }^{3)}$ Freshly prepared L. acidophillus KCTC 3925 cultures after grown in MRS at $37^{\circ} \mathrm{C}$ for $24 \mathrm{~h}$, were used.

\section{청국장 추출물 시료 제조}

발효된 청국장의 품질특성 분석을 위하여 2 차 발효가 완료된 청국장 시료에 9 배 부피의 증류수를 가하여 희석한 청국장을 1 시간 상온에서 방치하였다. 혼합액을 $2,800 \mathrm{rpm}$ 에서 10 분간 원심분리기(5816R, Eppendorf, Hamburg, Germany)로 원심분리하여 상층액을 회수하여 이를 청국장 추출물 시료로 사용하였다.

\section{일반성분 분석}

수분함량은 상압가열건조법으로 측정하였으며, 구체적 으로 시료를 $105^{\circ} \mathrm{C}$ 로 설정된 건조기(OF-12, Jeio Tech, Daejeon, Korea)에서 16시간 건조시킨 후 무게변화로 측정 하였다. 청국장 시료의 일반성분은 $\mathrm{AOAC}(13)$ 방법에 따라 다음과 같이 측정하였다. 조회분 함량 측정에는 $600^{\circ} \mathrm{C}$ 의 회화로(MF31G, Jeio Tech)에서 시료를 재가 될 때까지 회화 
시키는 직접회화법을 사용하였다. 조단백질은 킬달 분해장 치(Digestion unit K-424, Buchi, Flawil, Swizerland)로 시료 를 분해한 후 증류장치(Kjeflex K-360, Buchi)와 적정장치 (702 SMTirino Metrohm, Buchi)를 순차적으로 사용하고 최 종적인 단백질 함량은 질소계수 6.25 를 곱하여 산출하였다. 조지방 함량은 diethly ether를 용매로 하고 Soxhlet 장치 (E-806, Buchi)를 사용한 후 남은 용매는 건조기로 건조한 후 무게를 측정하였다. 탄수화물 함량은 수분을 제외한 조 단백, 조지방, 조회분의 측정값을 100 으로 감한 값으로 계 산하였다.

가용성 고형분, $\mathrm{pH}$ 및 점질물의 신장성 측정

청국장 추출물 시료를 제조한 후 가용성 고형분 및 $\mathrm{pH}$ 는 $\mathrm{Na}$ 등(14)의 방법에 따라 측정하였다. 가용성 고형분과 $\mathrm{pH}$ 는 각각 굴절당도계(Hand-held refractometer, Model N-1, ATAGO, Tokyo, Japan)와 $\mathrm{pH}$ meter(model 725p, Istek, Seoul, Korea)를 사용하여 측정하였다. 점질물의 신장성은 발효된 청국장 시료를 희석하지 않은 상태로 일정량 패드리 디쉬(petridish)에 넣고 약수저로 일정 높이까지 떠올려 늘 어나는 길이로 측정하였다. 총 30 회 반복하여 평균값을 나 타내었다.

\section{환원당 함량}

환원당 함량은 Chae 등(15)의 방법에 기초한 dinitrosalicylic $\operatorname{acid}(\mathrm{DNS})$ 법으로 측정하였다. 발효된 청국장 시료에 4 배 부피의 증류수를 가한 후 원심분리하여 회수한 상층액 시료 $0.1 \mathrm{~mL}$ 에 DNS 시약 $0.3 \mathrm{~mL}$ 을 가하여 $80^{\circ} \mathrm{C}$ 에서 5 분간 반응 시키고 흡광도 $550 \mathrm{~nm}$ 에서 측정하였다. 포도당을 사용하여 표준곡선을 작성한 후 환원당 함량을 산출하였다.

Reducing sugar $(\%)=\mathrm{A} \times \mathrm{D} \times 1 / \mathrm{S} \times 100 / 1,000$

$$
\begin{aligned}
& \mathrm{A} \text { : 시료 환원당 양 }(\mathrm{mg}) \\
& \mathrm{D} \text { : 희석배수 } \\
& \mathrm{S} \text { : 시료양 }(\mathrm{g})
\end{aligned}
$$

\section{아미노태 질소함량}

아미노태 질소 함량은 Choi 등(16)의 방법으로 다음과 같이 측정하였다. 5 배로 희석한 제조한 청국장 추출물 시료 $5 \mathrm{~mL}$ 에 $0.1 \mathrm{~N} \mathrm{NaOH}$ 를 첨가하여 $\mathrm{pH}$ 8.3으로 조정한 후 중성 formalin 용액(35-40\%) $20 \mathrm{~mL}$ 를 다시 가하고 $\mathrm{pH} 8.3$ 으 로 재적정하였으며, 공시험에는 증류수를 사용하였다.

$$
\text { 아미노태질소 }(\mathrm{mg} \%)=(\mathrm{A}-\mathrm{B}) \times 1.4 \times \mathrm{F} \times \mathrm{D} / \mathrm{S} \times 100
$$
$\mathrm{A}$ : 본 실험의 시료에 대한 $0.1 \mathrm{~N} \mathrm{NaOH}$ 표준용액의 적정소비량 $(\mathrm{mL})$
$\mathrm{B}$ : 공시험에 대한 $0.1 \mathrm{~N} \mathrm{NaOH}$ 표준액의 적정소비량 $(\mathrm{mL})$
$\mathrm{F}: 0.1 \mathrm{~N} \mathrm{NaOH}$ 용액의 factor

$$
\begin{aligned}
& \mathrm{D} \text { : 희석배수 } \\
& \mathrm{S} \text { : 시료 채취량 }(\mathrm{g})
\end{aligned}
$$

\section{암모니아태 질소함량 측정}

암모니아태 질소함량은 phenol-hypochloride법(17)으로 측정하였다. 5 배로 희석한 청국장 추출물 시료 $10 \mu \mathrm{L}$ 에 용액 $\mathrm{A}$ (phenol $10 \mathrm{~g}$, sodium nitroprusside dihydrate $0.05 \mathrm{~g}$ in $1 \mathrm{~L}$ water)와 용액 $\mathrm{B}\left(\mathrm{Na}_{2} \mathrm{HPO}_{4} \cdot 12 \mathrm{H}_{2} \mathrm{O} 9 \mathrm{~g}, \mathrm{NaOH} 6 \mathrm{~g}\right.$ and $\mathrm{NaOCl} 10 \mathrm{~mL}$ in $1 \mathrm{~L}$ water)를 각각 $100 \mu \mathrm{L}$ 씩 순차적으로 가하여 $37^{\circ} \mathrm{C}$ 에서 20 분간 반응한 후 $630 \mathrm{~nm}$ 에서 흡광도를 측정하였다. $(\mathrm{NH} 4)_{2} \mathrm{SO}_{4}$ 를 희석하여 제조한 시료를 표준용 액으로 사용하여 표준곡선을 작성한 후 암모니아태 질소 함량을 측정하여 작성하였다.

\section{$a-A m y l a s e$ 활성분석}

a-Amylase 활성 측정은 Joo 등(18)이 사용한 DUN(dextrinogenic unit of nagase) 방법에 따라 측정하였다. $1 \%$ 가용성전분(0.02 M phosphate buffer, $\mathrm{pH} 7.0) 0.3 \mathrm{~mL}$ 에 5 배로 희석한 청국장 추출물 시료 $0.1 \mathrm{~mL}$ 를 첨가하고 $40^{\circ} \mathrm{C}$ 의 항온수조에서 10 분 동안 반응하였다. 여기에 $0.1 \mathrm{~N} \mathrm{HCl}$ $1 \mathrm{~mL}$ 를 가한 후 $0.1 \mathrm{~mL}$ 를 취하여 요오드 용액 $(0.005 \%$ $\left.\mathrm{I}_{2}+0.05 \% \mathrm{KI}\right) 1 \mathrm{~mL}$ 로 발색시켜 $660 \mathrm{~nm}$ 에서 흡광도를 측정 하였다. 조효소액 $1 \mathrm{~mL}$ 가 1 분 동안 전분 $0.1 \mathrm{mg}$ 을 분해한 양을 1 unit의 a-amylase 활성으로 계산하였다.

\section{중성 protease 활성측정}

중성 protease 활성측정은 Lee 등(19)의 방법에 따라 실시 하였다. 5 배로 희석한 청국장 추출물 시료 $0.5 \mathrm{~mL}$ 에 $0.6 \%$ casein 기질용액(0.2 M phosphate buffer, $\mathrm{pH}$ 7.0)을 $1.5 \mathrm{~mL}$ 넣고 $37^{\circ} \mathrm{C}$ 에서 10 분 동안 반응시켰다. 이후, $0.44 \mathrm{M}$ trichloroacetic acid $2 \mathrm{~mL}$ 를 첨가하고 항온수조에서 25분 동안 반응을 진행하였다. 여과지(No.2, Whatman, Buckinghamshire, $\mathrm{UK}$ )로 침전된 단백질을 제거하고 $1 \mathrm{~mL}$ 를 취해 $0.55 \mathrm{M}$ $\mathrm{Na}_{2} \mathrm{CO}_{3}$ 용액 $5 \mathrm{~mL}$ 와 3 배 희석된 Folin-Ciocalteu's reagent 용액 $1 \mathrm{~mL}$ 를 첨가하여 $37^{\circ} \mathrm{C}$ 에서 20 분 동안 반응하였다. 최종 반응물은 흡광도 $660 \mathrm{~nm}$ 에서 측정하였으며, 표준물질 은 tyrosine을 사용하였다. 1 unit의 효소활성은 1 분 동안 tyrosine $1 \mathrm{\mu g}$ 을 유리시키는 양으로 정의하였다.

\section{이소플라본 정량}

비배당체 이소플라본 정량은 $\mathrm{Kim}$ 등(12)의 방법으로 측 정하였다. $80 \%$ ethanol로 10 배 희석한 청국장을 24 시간 정 치추출하고 $0.45 \mu \mathrm{m}$ 여과기로 여과하였다. 배당체 이소플 라본 정량을 위하여 청국장 시료 $2.5 \mathrm{~g}$ 과 $2 \mathrm{~N} \mathrm{HCl} 10 \mathrm{~mL}$ 를 혼합한 후 $97^{\circ} \mathrm{C}$ 에서 90 분 동안 산가수분해하였고 $10 \mathrm{~N}$ $\mathrm{NaOH}$ 를 가하여 $\mathrm{pH}$ 7로 중화하였다. 중화된 시료 용량의 9 배에 해당하는 $80 \%$ ethanol을 첨가하여 24시간 정치추출 하였다. 추출액을 여과하고 Eclipse $\mathrm{XDB}_{18}$ column 
$(4.6 \times 250 \mathrm{~mm}$ ID, Agilent Technologies, Santa Clara, CA, USA)이 장착된 HPLC(Agilent 1,200, Agilent Technologies) 에 $20 \mu \mathrm{L}$ 를 주입하였다. 용매의 유속과 retention time은 각각 $1.2 \mathrm{~mL} / \mathrm{min}$ 와 $90 \mathrm{~min}$ 였다. 이동상으로 용매 $\mathrm{A}(0.1 \%$ acetic acid in water)와 용매 $\mathrm{B}(0.1 \%$ acetic acid in acetonitrile) 을 사용하였다. 용매 $\mathrm{A}$ 와 용매 $\mathrm{B}$ 의 농도 기울기는 0-25 $\min (93: 7), \quad 25-50 \min (85: 15), 50-55 \min (80: 20), 55-70$ $\min (75: 25), 70-75 \min (75: 25), 75-80 \min (65: 35)$ 와 80-90 $\min (65: 35)$ 로 설정하였다. 칼럼에서 분리된 개별물질들은 $254 \mathrm{~nm}$ 로 설정된 $\mathrm{UV}$ detector에서 검출된 면적으로 정량분 석을 하였으며, 실험결과는 희석배수를 보정해 다음 식에 서 계산하였다.

$$
\text { 전환률 }(\%)=\frac{\text { 산가수분해 공정없이 정량한 비배당체 이소플라본 함량 }(\mathrm{mg} / \mathrm{kg})}{\text { 산가수분해 공정 후 측정한 비배당체 이소플라본 함량 }(\mathrm{mg} / \mathrm{kg})} \times 100
$$

\section{통계처리}

실험결과는 3회 반복하여 측정한 값을 평균(mean)과 표 준편차(SD)로 표시하였고, 실험결과의 통계적 유의성 분석 을 위해 SPSS를 사용하여 일원분산분석(one-way ANOVA) 을 실시하였고, 시료간의 유의성 평가는 Duncan's multiple range test를 실시하여 사후 검증하였다.

\section{결과 및 고찰}

\section{설탕 첨가 비율 최적화}

설탕 첨가비율 최적화 실험은 $\mathrm{Kim}$ 등(12)의 방법에 따라, 1 차 발효된 청국장 시료에 유산(lactic acid)을 첨가한 후
살균공정 첨가유무, 유산균 종균 사용유무, 설탕 첨가유무 를 달리하여 준비한 시료들(Table 1)을 2차 발효한 청국장 시료들의 $\mathrm{pH}$ 와 비배당체 이소플라본 함량을 각각 정량하 였다(Table 2). 설탕 무첨가군 청국장 시료들의 $\mathrm{pH}$ 는 6.38-6.88였지만, 2.5 와 $7.5 \%$ 설탕 첨가군 청국장 시료들의 $\mathrm{pH}$ 는 각각 5.12-5.17, 4.96-5.08로 나타나서 청국장의 $\mathrm{pH}$ 는 발효초기에 첨가된 설탕농도에 비례적으로 감소하였다. 설 탕 무첨가군에서 총 비배당체 이소플라본 함량은 Con, WS 와 WSS이 각각 $190.6,177.6$ 와 $217.5 \mathrm{mg} / \mathrm{kg}$ 으로 나타났다. 배양액 속에 포함된 설탕의 농도가 증가함에 따라 2차 발효 된 청국장에서 비배당체 이소플라본 함량이 농도의존적으 로 감소하는 경향을 보였다. 특히, 동일한 설탕농도에서는 WSS의 총 비배당체 이소플라본 함량은 대조군인 Con보다 높게 나타나 설탕 첨가 시 2 차 발효된 청국장 시료의 B-glucosidase 활성이 유의적으로 높았다 $(\mathrm{p}<0.05)$.

청국장 시료에서 $\mathrm{pH}$ 가 감소된 이유는 설탕이 종균을 포 함한 다른 미생물들의 생육을 위한 탄소원으로 사용되어, 유산 등의 유기산을 대사산물로 생성하기 때문이다(12). 2 차 발효전에 청국장 시료를 열처리하여 유산균 종균을 접종하여 제조한 청국장(WSS)과 대조군(Con)의 전체 비배 당체 이소플라본 함량을 비교 시 유산균 종균을 첨가한 시료에서 비배당체 이소플라본 함량이 증가하였다(Con vs WSS, Con(2.5S) vs WSS(2.5S), Con(7.5S) vs WSS(7.5S)). 이러한 결과는 2 차 발효에 사용한 종균인 L. acidophilus KCTC 3925의 B-glucosidase 활성이 우수하다는 것을 의미 한다(12). $7.5 \%$ 설탕 첨가군의 비배당체 이소플라본 함량이 $2.5 \%$ 설탕 첨가군보다 낮은 점을 고려하여 $2.5 \%$ 설탕을 사용한 WSS(2.5S)를 선택하여 후속연구를 실시하였다.

Table 2. Changes of $\mathrm{pH}$, and isoflavone contents of $2^{\text {nd }}$ fermented various Cheonggukjang with different sugar contents

\begin{tabular}{|c|c|c|c|c|c|}
\hline \multirow{2}{*}{ Groups $^{1)}$} & \multirow{2}{*}{$\mathrm{pH}$} & \multicolumn{4}{|c|}{ Aglycone-formed isoflavone (mg/kg) } \\
\hline & & Daidzein & Glycitein & Genistein & Sum \\
\hline Con & $6.75 \pm 0.01^{2 b 33)}$ & $76.6 \pm 8.0^{\mathrm{b}}$ & $13.0 \pm 1.4^{\mathrm{ab}}$ & $101.0 \pm 11.9^{\mathrm{ab}}$ & $190.6 \pm 21.1^{b}$ \\
\hline WS & $6.88 \pm 0.12^{\mathrm{a}}$ & $71.9 \pm 3.5^{\mathrm{b}}$ & $12.2 \pm 0.7^{\mathrm{ab}}$ & $93.4 \pm 4.4^{\mathrm{bc}}$ & $177.6 \pm 8.5^{\mathrm{bc}}$ \\
\hline WSS & $6.38 \pm 0.01^{\mathrm{c}}$ & $90.2 \pm 1.0^{\mathrm{a}}$ & $13.5 \pm 0.4^{\mathrm{a}}$ & $113.8 \pm 2.3^{\mathrm{a}}$ & $217.5 \pm 3.5^{\mathrm{a}}$ \\
\hline Con $(2.5 \mathrm{~S})$ & $5.12 \pm 0.01^{e}$ & $40.8 \pm 4.9^{\mathrm{ef}}$ & $8.7 \pm 1.0^{\mathrm{d}}$ & $56.5 \pm 9.1^{\mathrm{fg}}$ & $106.0 \pm 15.0^{\mathrm{fg}}$ \\
\hline WS $(2.5 S)$ & $5.17 \pm 0.01^{\mathrm{d}}$ & $52.3 \pm 4.3^{\text {cd }}$ & $10.2 \pm 0.9^{\mathrm{bc}}$ & $70.2 \pm 7.1^{\mathrm{ef}}$ & $132.8 \pm 12.3^{\mathrm{de}}$ \\
\hline WSS (2.5S) & $5.12 \pm 0.01^{\mathrm{e}}$ & $60.5 \pm 10.3^{c}$ & $12.6 \pm 1.7^{\mathrm{ab}}$ & $85.4 \pm 14.4^{\text {cd }}$ & $158.5 \pm 26.4^{\mathrm{c}}$ \\
\hline Con $(7.5 S)$ & $5.08 \pm 0.01^{\mathrm{f}}$ & $35.7 \pm 1.9^{f}$ & $6.2 \pm 3.3^{\mathrm{e}}$ & $46.8 \pm 2.5^{\mathrm{g}}$ & $88.8 \pm 6.7^{9}$ \\
\hline WS (7.5S) & $4.96 \pm 0.02^{\mathrm{g}}$ & $52.8 \pm 3.4^{\mathrm{cd}}$ & $10.6 \pm 0.4^{\mathrm{bc}}$ & $72.5 \pm 5.0^{\mathrm{de}}$ & $135.9 \pm 8.6^{\mathrm{de}}$ \\
\hline WSS (7.5S) & $5.03 \pm 0.01^{\mathrm{h}}$ & $49.4 \pm 2.2^{\mathrm{de}}$ & $10.7 \pm 0.8^{\mathrm{bc}}$ & $66.4 \pm 5.6^{\mathrm{ef}}$ & $126.5 \pm 8.6^{\mathrm{ef}}$ \\
\hline
\end{tabular}

${ }^{1)}$ Con, prior to $2^{\text {nd }}$ fermentation, either $0,2.5,7.5 \%$ of sucrose was supplemented to fermentation broth then $2^{\text {nd }}$ fermentation was carried out at $40{ }^{\circ} \mathrm{C}$ for $48 \mathrm{~h}$; WS, to fermentation broth containing $40 \mathrm{~g}$ of Cheonggukjang and $2 \%$ lactic acid, sucrose solution was supplemented as indicated in Table 1 and $2^{\text {nd }}$ fermentation was carried out at $40^{\circ} \mathrm{C}$ for $48 \mathrm{~h}$ using $L$ acidophilus KCTC 3925 ; WSS, To fermentation broth, sucrose solution was supplemented and then heat-sterilized at $100^{\circ} \mathrm{C}$, 15 min. $2^{\text {nd }}$ fermentation was carried out at $40^{\circ} \mathrm{C}$ for $48 \mathrm{~h}$ using L. acidophilus KCTC 3925.

${ }^{2)}$ All values are mean $\pm \mathrm{SD}(\mathrm{n}=3)$.

${ }^{3)}$ Means with different superscripts in the same column are significantly different at $\mathrm{p}<0.05$ by Duncan's multiple range test. 
일반성분, 가용성 고형물, 점질물의 신장성 측정

최적화를 통해 선택된 청국장의 일반성분을 분석한 결과 는 Table 3 에 나타내었다. $2.5 \%$ 설탕과 L acidophilus $\mathrm{KCTC}$ 3925 가 첨가된 $\mathrm{WSS}(2.5 \mathrm{~S})$ 청국장의 수분, 단백질, 탄수화 물, 지방, 회분은 각각 $57.85,41.20,43.04,10.96,4.81 \%$ 였으 며, $2.5 \%$ 설탕을 추가로 첨가하여 제조한 청국장인 $\operatorname{Con}(2.5 \mathrm{~S})$ 은 $61.73,42.67,40.70,11.98,4.56 \%$ 로 나타나 대 조군과 유의적인 차이를 나타내지 않았다. 가용성 고형물 의 경우, $\mathrm{WSS}(2.5 \mathrm{~S})$ 이 $2.67{ }^{\circ} \mathrm{Brix}$ 였고 $\mathrm{Con}(2.5 \mathrm{~S})$ 와 $\mathrm{Con}$ 의 경우 각각 3.40 과 $3.27{ }^{\circ} \mathrm{Brix}$ 로 측정되어 $\mathrm{WSS}(2.5 \mathrm{~S})$ 에서 유의적으로 낮았다 $(\mathrm{p}<0.05)(\mathrm{Fig}$. 1). 점질물의 신장성은 $\mathrm{WSS}(2.5 \mathrm{~S}), \mathrm{Con}(2.5 \mathrm{~S})$ 와 $\mathrm{Con}$ 에서 각각 24.4, 15.4와 13.1 $\mathrm{cm}$ 로 나타나서 유의적인 차이가 있었다(p<0.05)(Fig. 2).

Table 3. Proximate composition of three kinds of Cheonggukjang

\begin{tabular}{cccc}
\hline Proximate composition & Con $^{1)}$ & Con $(2.5 \mathrm{~S})$ & WSS (2.5S) \\
\hline Moisture (\%) & $58.97 \pm 1.49^{2 \mathrm{a} a)}$ & $61.73 \pm 1.65^{\mathrm{a}}$ & $57.85 \pm 1.55^{\mathrm{a}}$ \\
Crude protein (\%) & $43.54 \pm 2.93^{\mathrm{a}}$ & $42.67 \pm 1.06^{\mathrm{a}}$ & $41.20 \pm 0.55^{\mathrm{a}}$ \\
Carbohydrate (\%) & $40.06 \pm 2.79^{\mathrm{a}}$ & $40.70 \pm 0.76^{\mathrm{a}}$ & $43.04 \pm 1.34^{\mathrm{a}}$ \\
Crude fat (\%) & $11.59 \pm 0.52^{\mathrm{a}}$ & $11.98 \pm 0.347^{\mathrm{a}}$ & $10.96 \pm 0.97^{\mathrm{a}}$ \\
Crude ash (\%) & $4.81 \pm 0.10^{\mathrm{a}}$ & $4.56 \pm 0.03^{\mathrm{a}}$ & $4.81 \pm 0.06^{\mathrm{a}}$ \\
\hline
\end{tabular}

${ }^{1)}$ Con, prior to $2^{\text {nd }}$ fermentation, either $0,2.5,7.5 \%$ of sucrose was supplemented to fermentation broth then $2^{\text {nd }}$ fermentation was carried out at $40^{\circ} \mathrm{C}$ for $48 \mathrm{~h}$; WS, to fermentation broth containing $40 \mathrm{~g}$ of Cheonggukjang and $2 \%$ lactic acid, suctose solution was supplemented as indicated in Table 1 and $2^{\text {nd }}$ fermentation was carried out at $40^{\circ} \mathrm{C}$ for $48 \mathrm{~h}$ using $L$. acidophilus KCTC 3925 ; WSS, to fermentation broth, sucrose solution was supplemented and then heat-sterilized at $100^{\circ} \mathrm{C}, 15 \mathrm{~min}$. $2^{\text {nd }}$ fermentation was carried out at $40^{\circ} \mathrm{C}$ for $48 \mathrm{~h}$ using $L$ acidophilus KCTC 3925 . ${ }^{2)}$ All values are mean $\pm \mathrm{SD}(\mathrm{n}=3)$.

${ }^{3}$ Means with different superscripts in the same row are significantly different at $\mathrm{p}<0.05$ by Duncan's multiple range test.

L. acidophilus에 의하여 생성되는 exopolysaccharide로는 galactooligosaccharide와(20)와 포도당 중합체인 글루칸 (12)이 알려져 있다. 또한, Kim과 Lee(21)은 발효가 진행될 수록 $\mathrm{PGA}$ 의 함량은 증가하면서 분자량이 감소하였고 levan의 함량은 12 시간 이후 감소하였으며, PGA와 levan의 복합체인 점질물의 점성은 48 시간에서 가장 높았다. 따라 서, $\mathrm{WSS}(2.5 \mathrm{~S})$ 에서 당도가 낮고 점질물의 신장성이 길게 측정된 것은 2 차 발효시 첨가된 L acidophilus KCTC 3925 가 설탕을 기질로 사용하여 저분자량의 점질물을 생성한 결과로 판단된다.

\section{아미노태 및 암모니아태 질소, 환원당 함량}

아미노태 질소는 대두 발효식품의 구수한 맛을 나타내는 척도로 미생물의 protease에 의해 생산되는 아미노산을 나 타내는 지표이다. 또한, protease 활성과 비례적으로 유사한 경향이 있다 $(10,22)$. 아미노태 질소함량은 청국장 발효의 주요 지표중의 하나로 여겨지므로 그 함량을 측정하였다 (Table 4). WSS(2.5S)의 아미노태 질소함량은 $700.0 \mathrm{mg} \%$ 로

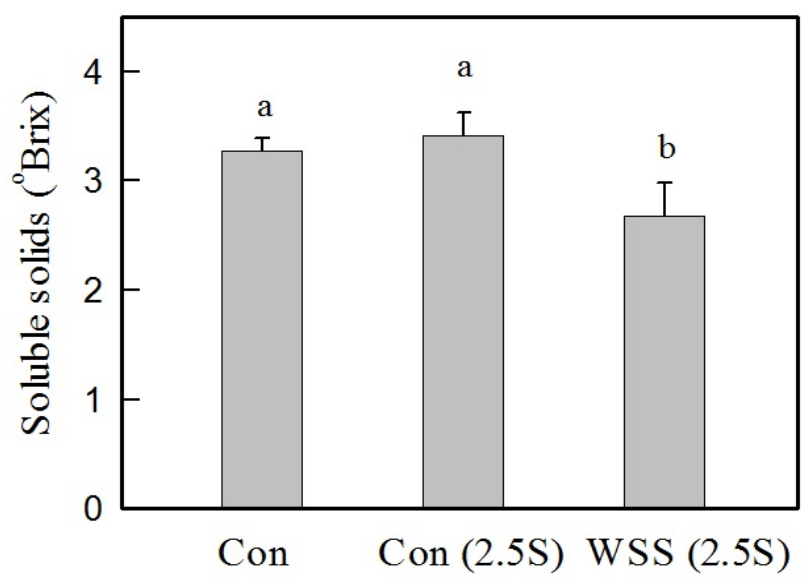

Fig. 1. Soluble solids contents of three kinds of Cheonggukjang.

Con, prior to $2^{\text {nd }}$ fermentation, either $0,2.5,7.5 \%$ of sucrose was supplemented to fermentation broth then $2^{\text {nd }}$ fermentation was carried out at $40^{\circ} \mathrm{C}$ for $48 \mathrm{~h}$; WS, to fermentation broth containing $40 \mathrm{~g}$ of Cheonggukjang and $2 \%$ lactic acid, sucrose solution was supplemented as indicated in Table 1 and $2^{\text {nd }}$ fermentation was carried out at $40^{\circ} \mathrm{C}$ for $48 \mathrm{~h}$ using $L$ acidophilus KCTC 3925 ; WSS, to fermentation broth, sucrose solution was supplemented and then heat-sterilized at $100^{\circ} \mathrm{C}, 15 \mathrm{~min} .2^{\text {nd }}$ fermentation was carried out at $40^{\circ} \mathrm{C}$ for $48 \mathrm{~h}$ using L. acidophilus KCTC 3925.

All values are mean \pm SD $(n=3)$. Means with different superscripts are significantly different at $\mathrm{p}<0.05$ by Duncan's multiple range test.

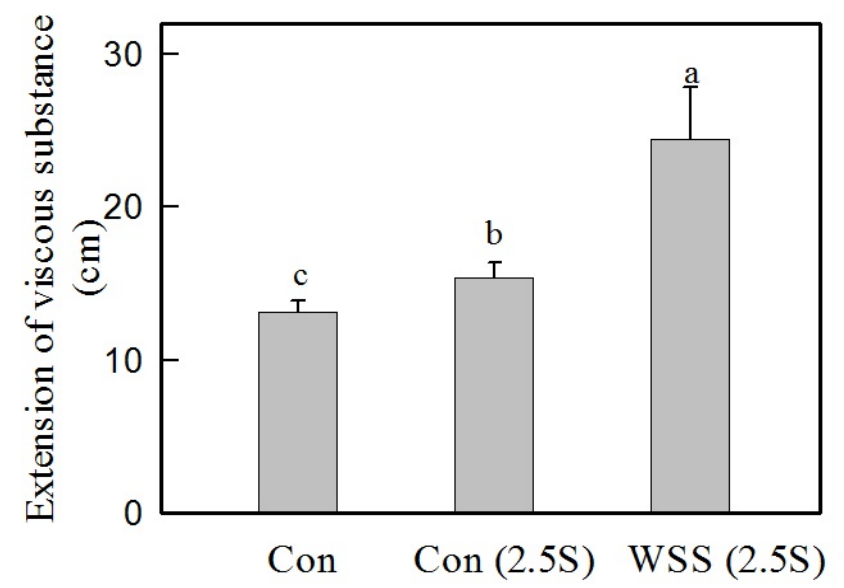

Fig. 2. Extension of viscous substance of three kinds of Cheonggukjang.

Con, prior to $2^{\text {nd }}$ fermentation, either $0,2.5,7.5 \%$ of sucrose was supplemented to fermentation broth then $2^{\text {nd }}$ fermentation was carried out at $40^{\circ} \mathrm{C}$ for $48 \mathrm{~h}$; WS, to fermentation broth containing $40 \mathrm{~g}$ of Cheonggukjang and $2 \%$ lactic acid, sucrose solution was supplemented as indicated in Table 1 and $2^{\text {nd }}$ fermentation was carried out at $40^{\circ} \mathrm{C}$ for $48 \mathrm{~h}$ using $L$ acidophilus KCTC 3925 ; WSS, to fermentation broth, sucrose solution was supplemented and then heat-sterilized at $100^{\circ} \mathrm{C}, 15 \mathrm{~min} .2^{\text {nd }}$ fermentation was carried out at $40^{\circ} \mathrm{C}$ for $48 \mathrm{~h}$ using L. acidophilus KCTC 3925 .

All values are mean \pm SD ( $n=3$ ). Means with different superscripts are significantly different at $\mathrm{p}<0.05$ by Duncan's multiple range test.

나타나서, $\operatorname{Con}(2.5 \mathrm{~S})$ 의 $793.3 \mathrm{mg} \%$ 나 대조군의 $966.0 \mathrm{mg} \%$ 보다는 유의적으로 낮았다 $(\mathrm{p}<0.05)$.

청국장 발효기간이 증가함에 따라 아미노태 질소 함량이 증가한다는 선행 연구와 48시간 발효된 청국장의 아미노태 질소 함량은 $197-603 \mathrm{mg} \%$ 로 측정된 Lee 등(22)의 연구와 비교 시 본 연구에서 측정된 3종 청국장 시료들의 아미노태 질소함량이 더 높게 나타났다. 특히, $\mathrm{WSS}(2.5 \mathrm{~S})$ 은 $L$. 
acidophilus KCTC 3925의 생육이 진행됨에 따라 고초균의 생육이 억제되는 것으로 판단할 수 있으며, 유사한 이유로 $\mathrm{Con}(2.5 \mathrm{~S})$ 군에서도 설탕이 1 차 청국장 발효 시 생성된 여러 가지 미생물들의 생육을 촉진하는 것으로 생각된다.

암모니아태 질소는 변패 또는 이상발효의 지표로 단백질 분해과정 중 deamination에 의하여 생성되고 과량 생산 시 에는 불쾌취로 작용해 청국장 품질저하의 원인이 된다 (23)(Table 4). 본 연구에서 제조된 청국장의 암모니아태 질소는 $\mathrm{Con}, \mathrm{Con}(2.5 \mathrm{~S}), \mathrm{WSS}(2.5 \mathrm{~S})$ 가 각각 $113.9,96.6$, $160.1 \mathrm{mg} \%$ 로 측정되었으며 각 시료들 간 유의적인 차이는 없었다.

본 연구결과는 선행연구에서 고초균에 $L$ plantarum 또는 $L$ saket를 첨가하여 제조한 청국장의 암모니아태 질소 함량 을 50.4-213.4 $\mathrm{mg} \%$ 로 보고한 결과 $(10,11)$ 와 유사하였다. 환원당은 환원당류인 glucose, fructose, maltose 등의 함 량을 나타내고 식품에 단맛을 부여하는 물질이다(23). Con, $\mathrm{Con}(2.5 \mathrm{~S}), \mathrm{WSS}(2.5 \mathrm{~S})$ 의 환원 당 함량은 각각 $0.55,0.47$, $0.57 \%$ 로 각 군들간 사이의 유의적인 차이는 없었다(Table 4). $\mathrm{Kim}$ 등(24)은 순창지역 청국장의 환원당 함량이 0.18-0.73\% 였다고 보고하여 본 연구에서 측정한 청국장 시 료들의 환원당 함량과 유사하였다.

Table 4. Amino-type nitrogen, ammonia-type nitrogen, and reducing sugar contents of three kinds of Cheonggukjang

\begin{tabular}{cccc}
\hline Type & Con $^{1)}$ & Con (2.5S) & WSS (2.5S) \\
\hline Amino-type nitrogen (mg\%) & $966.0 \pm 0.0^{2 / \mathrm{a} 3)}$ & $793.3 \pm 113.2^{\mathrm{b}}$ & $700.0 \pm 61.0^{\mathrm{b}}$ \\
Ammonia-type nitrogen (mg\%) & $113.9 \pm 32.1^{\mathrm{a}}$ & $96.6 \pm 20.9^{\mathrm{a}}$ & $160.1 \pm 39.8^{\mathrm{a}}$ \\
Reducing sugar contents (\%) & $0.55 \pm 0.08^{\mathrm{a}}$ & $0.47 \pm 0.10^{\mathrm{a}}$ & $0.57 \pm 0.10^{\mathrm{a}}$ \\
\hline
\end{tabular}

${ }^{1)}$ Con, prior to $2^{\text {nd }}$ fermentation, either $0,2.5,7.5 \%$ of sucrose was supplemented to fermentation broth then $2^{\text {nd }}$ fermentation was carried out at $40^{\circ} \mathrm{C}$ for $48 \mathrm{~h}$; WS, to fermentation broth containing $40 \mathrm{~g}$ of Cheonggukjang and 2\% lactic acid, sucrose solution was supplemented as indicated in Table 1 and $2^{\text {nd }}$ fermentation was carried out at $40^{\circ} \mathrm{C}$ for $48 \mathrm{~h}$ using $L$. acidophilus KCTC 3925; WSS, to fermentation broth, sucrose solution was supplemented and then heat-sterilized at $100^{\circ} \mathrm{C}, 15 \mathrm{~min}$. $2^{\text {nd }}$ fermentation was carried out at $40^{\circ} \mathrm{C}$ for $48 \mathrm{~h}$ using $L$ acidophilus KCTC 3925 . ${ }^{2)}$ All values are mean $\pm \mathrm{SD}(\mathrm{n}=3)$.

${ }^{3}$ Means with different superscripts in the same row are significantly different at $p<0.05$ by Duncan's multiple range test.

\section{a-Amylase 및 protease 활성}

a-Amylase는 식품속의 전분을 저분자량화하고 이때 생 성된 단당류 등의 저분자물질들은 감미 성분을 증진시켜 청국장 발효 품질을 향상시키는 중요한 효소이다(Table $5)(18,23)$. Con, Con(2.5S)와 WSS(2.5S)의 a-amylase 활성은 각각 $23.6,25.9$ 와 $32.9 \mathrm{unit} / \mathrm{mL}$ 로 측정되었으며 각 군들 사이의 유의적인 차이가 없었다. B. subtilis $\mathrm{HJ} 18-3$ 과 KACC 15935 를 사용하여 제조한 청국장의 a-amylase 활성은 11.5-29.7 unit/mL 였으며, B. subtilis HJ 18-9와 HJ 25-8를 종균으로 제조한 청국장은 6.8-12.1 unit/mL로 측정되어 연 구자별 청국장 시료의 a-amylase 활성 차이가 있었다
$(23,25,26)$. Protease는 청국장 제조 시 대두 단백질을 아미 노산, 폴리펩타이드 등으로 분해하고 구수한 맛을 나타내 는 지표로 아미노태 질소와 연관성이 높다(Table 5)(11). Con의 protease 활성은 445.5 unit $/ \mathrm{mL}$ 였으며, Con(2.5S)과 $\mathrm{WSS}(2.5 \mathrm{~S})$ 의 protease 활성은 각각 200.9 와 $154.6 \mathrm{unit} / \mathrm{mL}$ 로 나타나서 $\operatorname{WSS}(2.5 \mathrm{~S})$ 에서 유의적으로 낮았다 $(\mathrm{p}<0.05)$.

Lee 등(26)은 종균과 청국장 발효조건이 효소들의 활성 을 결정하는 주요 원인으로 제시하였다. 고초균과 유산균 을 종균으로 사용하여 청국장을 제조한 $\mathrm{Ju}$ 와 $\mathrm{Oh}$ 의 연구(11) 에서는 고초균을 단일사용 시 protease 활성은 177.0 unit/mL였으며, 고초균을 배양한 후 유산균을 접종 시 136.4 unit $/ \mathrm{mL}$, 고초균과 유산균을 동시접종 시에는 110.2 unit $/ \mathrm{mL}$ 로 나타나서 유산균의 생육이 고초균의 생육을 억제한다고 보고하여 본 연구에서 확인된 WSS(2.5S)의 낮은 protease 효소활성 결과와 일치하였다.

이상의 결과들을 정리해보면, 청국장 발효 시 설탕 (2.5-7.5\%)의 첨가는 후속발효에서 유산균의 생육을 촉진 하여 청국장의 $\mathrm{pH}$ 를 산성화시키고 비배당체 이소플라본 함량을 감소시킨다. 하지만, 설탕첨가는 유산균 유래의 $\beta$ -glucosidase 활성을 증가시키고 청국장 점질물의 물성에 변화를 주었다. 본 연구는 $\beta$-glucosidase 활성이 있는 유산 균을 추가적으로 종균으로 사용하여 비배당체 이소플라본 함량의 추가적인 생성을 기대하였으나 단일 균주로 접종하 여 제조한 청국장에서 더 높은 비배당체 이소플라본 생성을 확인하였다. 그럼에도 불구하고, 본 연구는 설탕과 $\beta$ -glucosidase 활성이 높은 유산균을 사용 시 비배당체 이소 플라본 생성의 감소를 낮추면서 청국장 점질물의 특성을 개선시킨다는 결론을 얻을 수 있었다.

Table 5. Enzyme activities of three kinds of Cheonggukjang (unit: unit/mL)

\begin{tabular}{cccc}
\hline Enzyme & $\operatorname{Con}^{1)}$ & Con $(2.5 S)$ & WSS $(2.5 S)$ \\
\hline a-amylase & $23.6 \pm 6.1^{\left.2)^{23}\right)}$ & $25.9 \pm 6.8^{\mathrm{a}}$ & $32.9 \pm 10.0^{\mathrm{a}}$ \\
Protease & $445.5 \pm 86.7^{\mathrm{a}}$ & $200.9 \pm 97.0^{\mathrm{b}}$ & $154.6 \pm 57.9^{\mathrm{b}}$ \\
\hline
\end{tabular}

${ }^{1)}$ Con, prior to $2^{\text {nd }}$ fermentation, either $0,2.5,7.5 \%$ of sucrose was supplemented to fermentation broth then $2^{\text {nd }}$ fermentation was carried out at $40^{\circ} \mathrm{C}$ for $48 \mathrm{~h}$; WS, to fermentation broth containing $40 \mathrm{~g}$ of Cheonggukjang and $2 \%$ lactic acid, sucrose solution was supplemented as indicated in Table 1 and $2^{\text {nd }}$ fermentation was carried out at $40^{\circ} \mathrm{C}$ for $48 \mathrm{~h}$ using $L$ acidophilus KCTC 3925 ; WSS, to fermentation broth, sucrose solution was supplemented and then heat-sterilized at $100^{\circ} \mathrm{C}, 15 \mathrm{~min}$. $2^{\text {nd }}$ fermentation was carried out at $40^{\circ} \mathrm{C}$ for $48 \mathrm{~h}$ using $L$ acidophilus KCTC 3925 . ${ }^{2)}$ All values are mean \pm SD $(n=3)$.

${ }^{3)}$ Means with different superscripts in the same row are significantly different at $p<0.05$ by Duncan's multiple range test.

\section{요 약}

본 연구에서는 청국장 제조 시 고초균(B. subtilis)과 유산 균인 $L$ acidophilus균 복합사용이 청국장 품질 특성에 미치 
는 영향을 연구하였다. 타 장류와 달리, 청국장은 과당중합 체와 폴리감마글루탐산의 복합체인 점질물질을 생성한다. 본 연구에서는 일반적인 청국장 발효과정(1차 발효) 후에 설탕 $(0,2.5,7.5 \%)$ 을 첨가하고 균체외 다당류 생성능이 있 는 유산균을 첨가하여 추가적으로 $40^{\circ} \mathrm{C}$ 에서 48 시간 동안 2 차 발효하였다. 2 차 발효된 청국장 시료들의 가용성 고형 분, 점질물의 신장성, $\mathrm{pH}$, 환원당, 아미노태 질소함량, 암모 니아태 질소함량, a-amylase, 및 protease 활성 측정, 이소플 라본 함량을 평가하였다. 2 차 발효 공정에서 설탕의 추가적 인 첨가는 청국장 시료의 $\mathrm{pH}$, 비배당체 이소플라본 함량, 아미노태 질소함량과 protease 활성을 저하시킨 반면, 청국 장 점질물의 신장성과 산(acid) 생성 미생물의 생육을 증가 시켰다. 결론적으로, 본 연구에서는 청국장 제조 시 $B$. subtilis과 L. acidophilus균 복합사용이 청국장 점질물질의 생성을 촉진하고 청국장 품질 특성을 변화시킨다는 것을 보여준다.

\section{감사의 글}

이 논문은 2017년도 정부(교육부)의 재원으로 한국연구 재단의 지원을 받아 수행된 기초연구사업임(No. NRF2017R1D1A3B03034313).

\section{References}

1. Choi EJ, Lee JS, Chang HB, Lee MS, Jang HD, Kwon YI (2010) Changes in the functionality of Cheonggukjang during fermentation supplemented with Angelica gigas, Rehmanniae radix, and red ginseng. Korean J Microbiol Biotechnol, 38, 467-474

2. Lee BY, Kim DM, Kim KH (1991) Physico-chemical properties of viscous substance extracted from Chungkook-jang. Korean J Food Sci Technol, 23, 599-604

3. Kang SJ, Kim SS, Chung HY (2014) Comparison of physicochemical characteristics and consumer perception of Cheongkukjang. J Korean Soc Food Sci Nutr, 43, 1104-1111

4. Jeong TS, Kim JH, An SA, Won YD, Lee SH (2013) Effect of black garlic on antioxidant activity and amino acids composition in Cheonggukjang. Korean J Food Preserv, 20, 643-649

5. Park JH, Kim JM, Park EJ, Lee KH (2008) Effects of Chungkukjang added with onion on lipid and antioxidant metabolisms in rats fed high fat-cholesterol diet. J Korean
Soc Food Sci Nutr, 37, 1244-1250

6. Moon JH, Choi IW, Park YK, Kim YS (2011) Development of natural meat-like flavor based on maillard reaction products. Korean J Food Sci Ani Resour, 31, 129-138

7. Kim MJ, Koh EM, Surh JH, Kim Lee YK, Kwon HJ (2003) Distribution of isoflavones and coumestrol in legumes and their products consumed in Korea. Food Sci Biotechnol, 12, 278-284

8. Chambert R, Haddaoui EA, Petit-Glatron MF (1995) Bacillus subtilis levansucrase: The efficiency of the second stage of secretion is modulated by external effectors assisting folding. Microbiology, 141, 997-1005

9. Khalil IR, Irorere VU, Radecka I, Burns ATH, Kowalczuk M, Mason JL, Khechara MP (2016) Poly-8 -glutamic acid: biodegradable polymer for potential protection of beneficial viruses. Materials, 9, 1-13

10. Lee GY, Kim SI, Jung MG, Seong JH, Lee YG, Kim HS, Chung HS, Lee BY, Kim DS (2014) Characteristics of Chungkookjang that enhance the flavor and GABA content in a mixed culture of Bacillus subtilis MC 31 and Lactobacillus sakei 383. J Life Sci, 24, 1102-1109

11. Ju KE, Oh NS (2009) Effect of the mixed culture of Bacillus subtilis and Lactobacillus plantarum on the quality of Cheonggukjang. Korean J Food Sci Technol, 41, 399-404

12. Kim JS, Lee JH, Surh JH, Kang SA, Jang KH (2016) Aglycone isoflavones and exopolysaccharides produced by Lactobacillus acidophilus in fermented soy bean paste. Prev Nutr Food Sci, 21, 117-123

13. AOAC (1996) Official methods of analysis. $15^{\text {th }} \mathrm{ed}$, Association of Official Analytical Chemists, Washington DC, USA, p 210-219

14. Na HG, Jang EH, Nam DH, Kim MA, Kim MJ, Sohn EH, Kim HD, Jang KH (2018) Physicochemical properties and isoflavone content of Chaga Cheonggukjang added with Lactobacillus acidophilus KCTC 3925 as a starter. Korean J Food Preserv, 25, 221-228

15. Chae SK, Kang KS, Ma SJ, Bang GW, Oh MH, Oh SH (2000) Standard food analysis, Jigu Publishing Co, Paju, Korea, p 299-301

16. Choi HS, Joo SJ, Yoon HS, Kim KS, Song IG, Min KB (2007) Quality characteristics of Hwangki (Astragalus membranaceus) Cheonggukjang during fermentation. Korean J Food Preserv, 14, 356-363

17. Hwang HA, Lee NK, Cho IJ, Hahm YT, Kwon KO, Kim BY (2008) Selection of microorganism and 
optimization of manufacture process for Cheonggukjang. Korean J Food Sci Technol, 40, 406-411

18. Joo HK, Kim ND, Yoon KS (1989) Changes of enzymatic activities during the fermentation of soybean-soypaste by Aspergillus spp.. J Korean Agric Chem Soc, 32, 295-302

19. Lee SY, Eom JS, Choi HS (2014) Quality characteristics of fermented soybean products by Bacillus sp. isolated from traditional soybean paste. J Korean Soc Food Sci Nutr, 43, 756-762

20. Tsuda H (2013) Exopolysaccharides of lactic acid bacteria for food and colon health applications. In: Lactic acid bacteria, Kongo JM (Editor), InTechOpen Co, London, UK, 515-538

21. Kim JE, Lee SB (2010) Evaluation of radical scavenging activity and physical properties of textured vegetable protein fermented by solid culture with Bacillus subtilis HA according to fermentation time. J Korean Soc Food Sci Nutr, 39, 872-879
22. Lee YL, Kim SH, Choung NH, Yim MH (1992) A study on the production of viscous substance during the Chungkookjang fermentation. J Korean Agric Chem Soc, 35, 202-209

23. Lee KH, Choi HS, Hwang KA, Song J (2016) Quality changes in Doenjang upon fermentation with two different Bacillus subtilis strains. J East Asian Soc Diet Life, 26, 163-170

24. Kim JW, Kim YS, Jeong PH, Kim HE, Shin DH (2006) Physicochemical characteristics of traditional fermented soybean products manufactured in folk villages of Sunchang region. J Food Hyg Saf, 21, 223-230

25. Lee KH, Choi HS, Choi YH, Park SY, Song J (2014) Changes in isoflavone content and quality characteristics of Cheonggukjang prepared with Bacillus subtilis HJ18-3 and KACC 15935. Korean J Food Preserv, 21, 121-128

26. Lee KH, Choi HS, Hwang KA, Song J (2016) Changes in biological qualities of soy grits Cheonggukjang by fermentation with $\beta$-glucosidase-producing Bacillus strains. J Korean Soc Food Sci Nutr, 45, 702-710 